\title{
FEATURE What's up? Examining the awareness of green roofs in suburbia
}

\author{
Rob Kuper
}

\section{"GREEN WHAT?"}

The cold weather and repetitive requests were affecting my speech. I repeated more slowly and with emphasis: "Are you interested in taking a two-minute survey about green roofs?" Overall 100 passersby stopped to take a 16-item questionnaire en route to or from class on two days in early December 2008 at Temple University in suburban Ambler, Pennsylvania.

To the surprise of many, a green roof was a three-minute walk away. The lack of signage, form and location of the building, and the topography of the site all contribute to making the green roof invisible. Nonetheless, the green roof atop the Athletics Building is one reason why Ambler, 15 miles north of the main Philadelphia campus, is Temple University's "green" campus.Ambler is also home to the Department of Landscape Architecture and Horticulture, Department of Community and Regional Planning, and the Center for Sustainable Communities.

With increasing national popularity of green roofs and the presence of one on campus, I wondered: What do suburban students know about green roofs? The survey results show that a majority of respondents were neutral to statements pertaining to green roof construction, cost, maintenance, and appearance, and their ecological benefits. This differs from elsewhere in the suburbs where few examples of green roofs exist. Dr. Carl Smith and Mark Boyer (Smith and Boyer 2007) of the University of Arkansas found that suburban residents were ambivalent toward or completely against implementing green roofs in their neighborhoods. The appearance of green roofs, they suggest, is likely to blame. In 2005 Meg Calkins (Calkins 2005) polled landscape architects who said clients had at least three concerns about green roofs: leaking, insurance risks, and high initial costs. Why the difference

Rob Kuper is an assistant professor of Landscape Architecture at Temple University, Ambler, Pennsylvania. in perception-neutral and negative? Home ownership may be a major factor. A majority of respondents at Temple lived with family members or rented and were not involved with the costs, maintenance, risks, and knowledge associated with owning a home. In time, they may be the next generation of homeowners. To get green roofs over their heads, what do they need to know?

A ground-based replica, interpretive and wayfinding signage, Web camera, and time-lapsed films are a few ways we are educating students and visitors at Ambler. Web pages and social networking on the Internet may be other ways to disseminate information. However, what can serve as a guide for devising methods of communication? What information is critical in convincing others to adopt green roofs?

\section{FIVE CONDITIONS RELATED TO THE ADOPTION OF GREEN ROOFS}

Calkins (Calkins 2005) outlines Rogers' "classical diffusion theory" in her article, "Strategy use and challenges of ecological design in landscape architecture." The classical diffusion theory states that five conditions must be satisfied before any new idea or strategy becomes widely accepted. If some or all of five conditions are not met, the strategy is less likely to be adopted. For green roofs to become more widely accepted and present in the landscape, they (1) must be simple to understand, (2) have relative economic

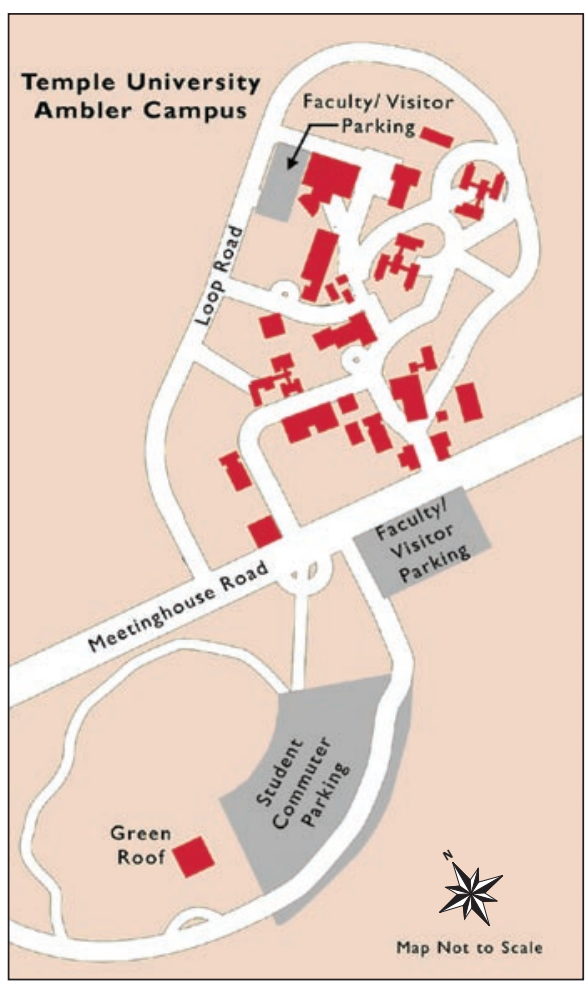

The Temple University Ambler Campus showing the location of the green roof in relation to the student commuter parking lot.

and ecological advantages, (3) be observed elsewhere, (4) be compatible with existing materials and methods, and (5) be easy to try.

Simple to Understand. Respondents in Calkins' survey said green roofs appeared complex. In comparison to a typical shingled roof, green roofs are more complex. Rather than wood, tarpaper, and an imper-

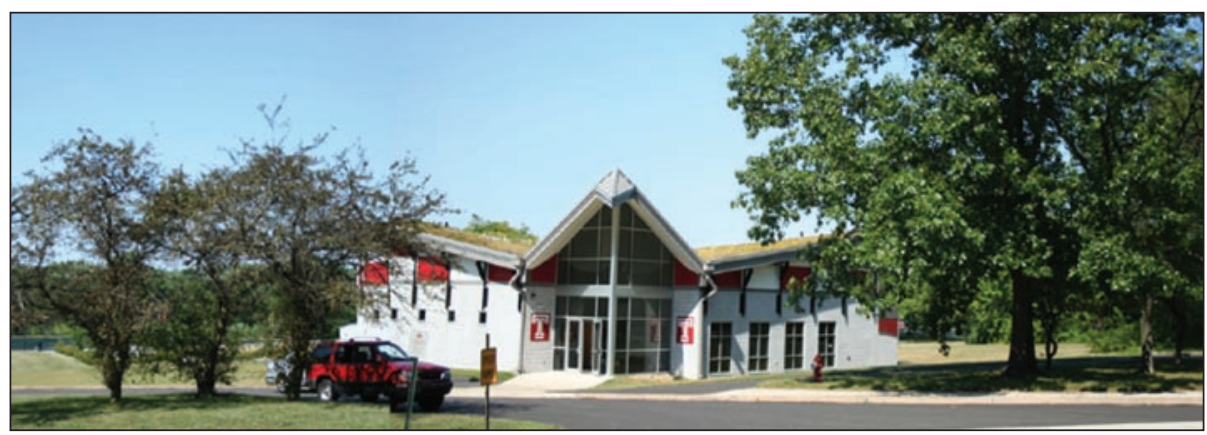

The best vantage point of the green roof atop the Ambler Athletics Building is directly in front of and across the road providing access to the student commuter lot. The internally pitched V-shaped roof, remote location, and topographic siting (on a hill) of the building make seeing the green roof from anywhere but here difficult. 


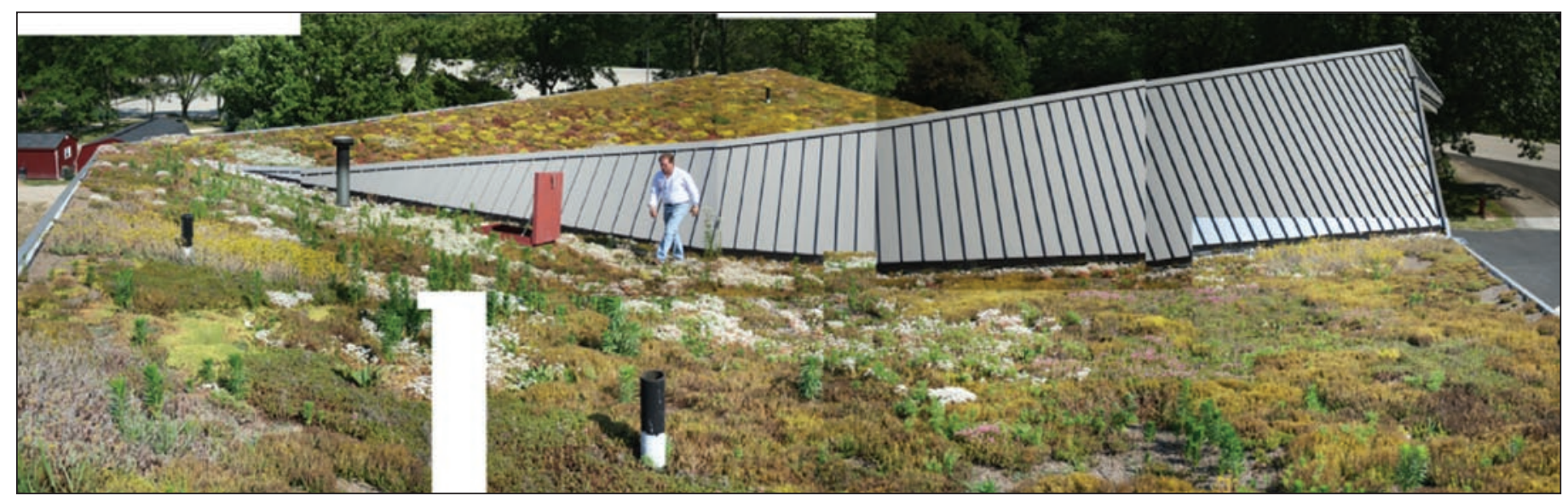

Atop the Ambler Athletics Building and the green roof in late June of 2008.

vious layer such as asphalt or slate shingles, green roofs have multiple layers, each specifically assigned to perform a different and essential task to keep the roof alive and functioning properly. Homeowners may perceive that more layers introduce problems requiring more attention, time, and money.

Relative Economic and Ecological Advantages. Calkins found cost to be the most frequently cited obstacle in adopting strategies like green roofs. In addition, she found that ecological advantages such as the reduction of stormwater runoff are not persuasive enough to encourage investment in a green roof. The longterm economic benefits, which include improved energy efficiency in buildings and an extended lifespan of the roofing membrane and structure beneath the green roof, Calkins writes, must be made more available to suburban residents and better quantified with further research.

Observed Elsewhere. Of all green strategies, green roofs are one of the most visible. Calkins notes that observable examples of green roofs using site visits or photographs are integral to increasing the adoption of green roofs. Two things have prevented the relatively high visibility of green roofs from increasing adoption rates thus far: first, there are few examples for suburban residents to observe; second, suburban residents may not like how green roofs look. As Smith and Boyer say in Green Places, suburban residents are more likely to accept green roofs if they do not look out of place. Myriad of multicolored mounds and brown leaves and stems following the flowers of Sedums, the predominant genus selected for green roofs, may conflict with the green, well-manicured preferences of western landscape aesthetics.

Compatible with Existing Materials and Methods. There is another conflict: green roofs differ from typical shingled roofs in the use of roofing materials and methods of construction. The roof structure beneath a green roof must support the additional weight of substrate when wet or dry. The eaves of green roofs must contain the substrate. The roof may require slope stabilization cells or netting to prevent substrate slippage and plant loss. Drainage, root penetration prevention, and electronic leak inspection, to name a few other technical aspects, are necessary. Contractors may resist learning about these materials and techniques. Materials may also prove difficult to locate and purchase.

Easy to Try. Green roofs are alive! The sun, rain, hail, snow, and wind alter the state of the roof. Installing a green roof on a suburban home requires an initial cost and follow-up costs for modifications and experiments. It may take several years and an economic investment to establish a green roof. As landscape architect Tom Liptan (Liptan 2005) found, the concept and construction of a green roof is relatively simple but experiments with irrigation, mowing, fertilization, and pest control follow and may deter homeowners from installing them on their own.

The questionnaire conducted at Temple University generally focused on each condition of the classical diffusion theory above. Informational deficiencies revealed in analyzing the results are guiding green roof education at Temple University.

\section{RESPONSES TO THE GREEN ROOF QUESTIONNAIRE AT TEMPLE}

The 100 respondents who completed the questionnaire at Ambler were asked about their familiarity with green roofs and their personal feelings of having green roofs in their own neighborhood. In addition, they were asked about the expense, appearance, maintenance, and life span of the structure beneath green roofs as well as whether green roofs reduced the potential for flooding and could decrease the air temperature in cities.

The respondents were evenly split between males and females. A majority (72) were under 25 years old and students. Respondents had full- or part-time jobs in retail or sales, or office-related positions such as a bank teller, realtor, or medical technologist. A few (8) had landscaperelated work in a nursery, performing landscape maintenance, or as a floral assistant. A majority of respondents had high school diplomas or associate's degrees. A wide variety of majors were represented in the survey, from marketing and accounting to finance and education. Eleven respondents majored in landscape architecture, horticulture, or community and regional planning. Seventy-one respondents lived in an area they classified as a suburb. Only 14 respondents owned their residence. The vast majority (63) lived with family members such as parents.

Most respondents (52) stated they did not know anything about green roofs. A majority of respondents were neutral about having green roofs in their own neighborhood. The vast majority neither agreed nor disagreed that green roofs are 
expensive, attractive, can decrease flooding after storms, reduce the air temperature in cities, require much maintenance, and that the roof structure beneath a green roof outlasts the structure beneath a shingled roof.

More detailed analysis revealed that a fair amount of respondents found green roofs attractive, believed green roofs could help decrease flooding after storms, and could reduce the air temperature in cities. Very few respondents had strong perceptions against green roofs. Slightly more respondents agreed than disagreed that green roofs require much work and maintenance. Similarly, more respondents agreed than disagreed that green roofs are expensive. The number of respondents who agreed equaled those who disagreed that the roof structure beneath a green roof outlasts the structure beneath a shingled roof.

The results of this survey indicate that the five conditions of the classical diffusion theory have not been satisfied among the respondents, many of whom may become future homeowners. Green roofs will not become more widespread in their neighborhoods with insufficient information about green roofs. Had many responses been negative, changing the minds of the respondents would be difficult. The respondents, however, were neutral and may be more receptive to learning about green roofs. Places of education, such as college campuses, are opportune locations for such an education about green roofs and may aid future green roof adoption.

\section{GREEN ROOF EDUCATION AT TEMPLE UNIVERSITY}

The classical diffusion theory and questionnaire results are directing the green roof education of students and campus visitors at Ambler. To date, we have begun four small projects on or near the site of the green roof that address some of the five conditions in the classical diffusion theory: bolstering planting along the edge of the green roof, designing and constructing a ground-based replica, installing interpretive and wayfinding signage, and installing a Web camera to create time-lapsed films. Completely satisfying the five conditions of the theory, we have concluded, cannot be done on site. A Web page and other

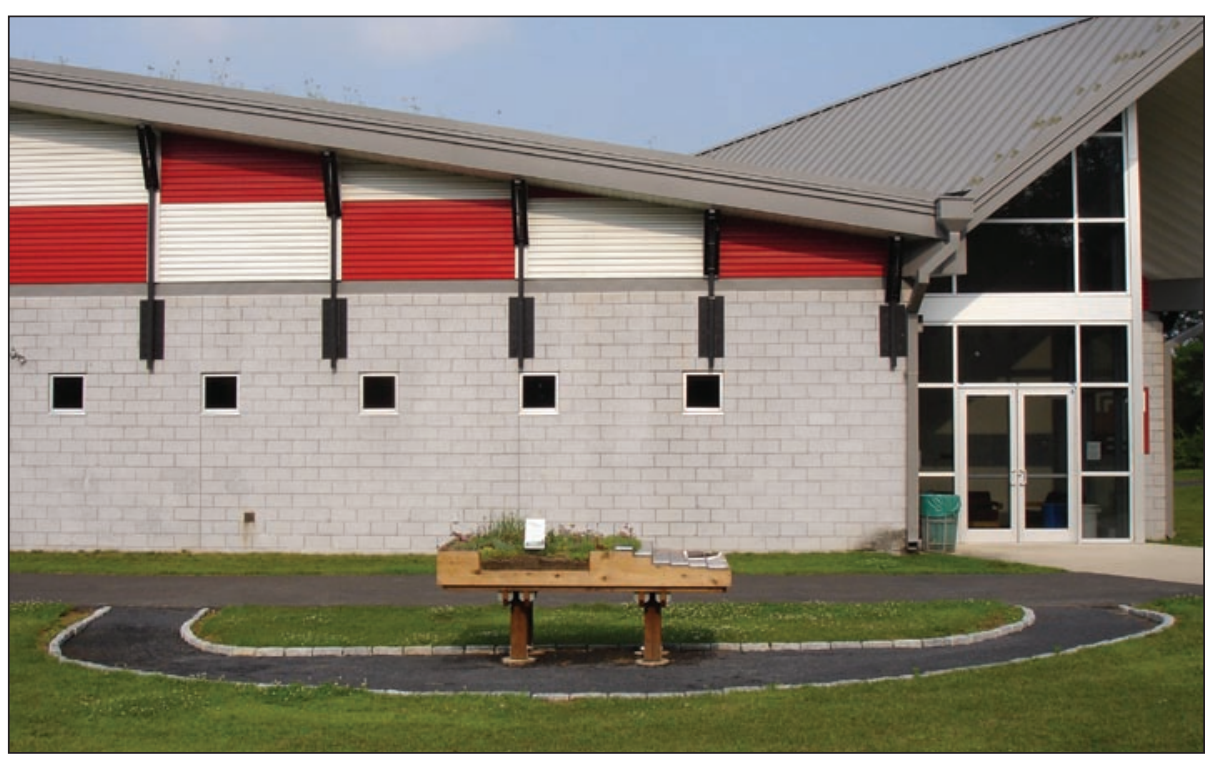

The ground-based green roof replica in front of the Athletics Building. The bolstered perimeter planting is getting established and is expected to make the roof more visible from the ground.

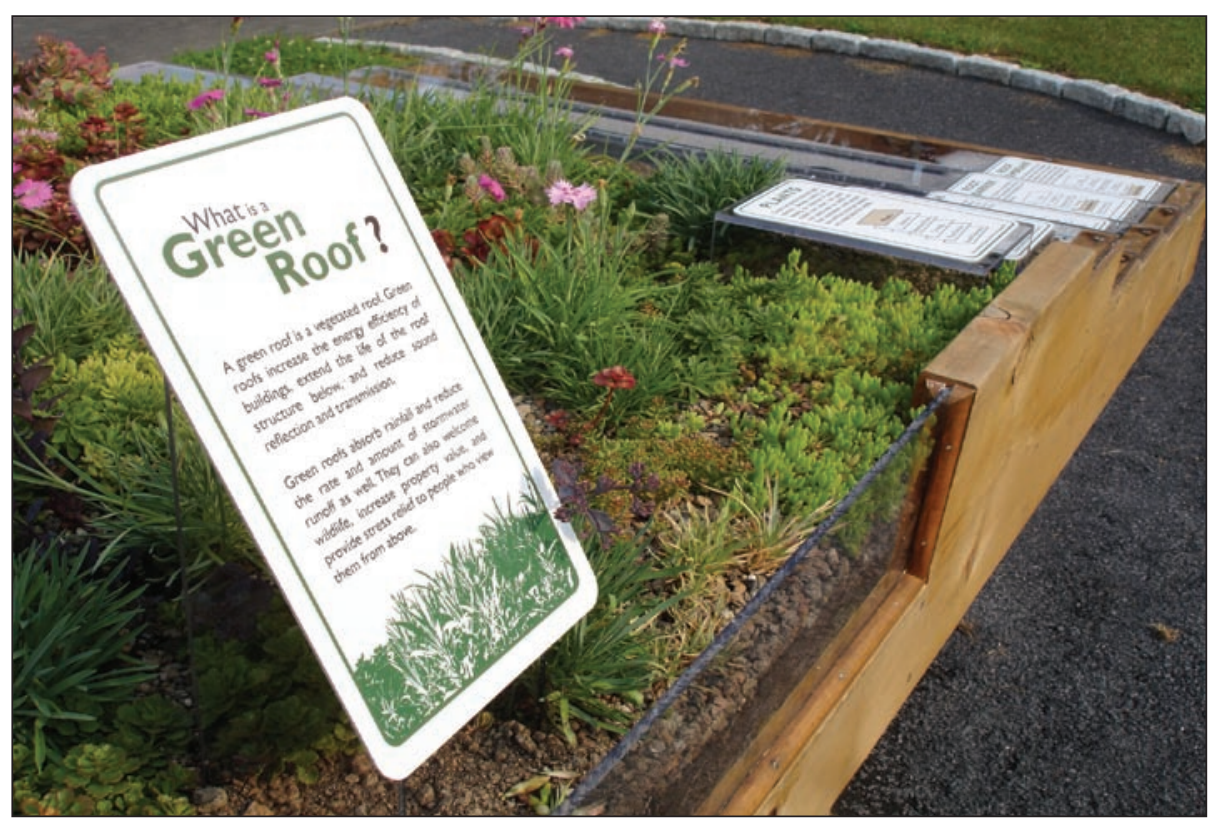

The ground-based green roof replica and signage.

Internet-based media may be the best way of disseminating economic, structural, and life-cycle information about green roofs. Digital media are included here, along with the four projects currently underway, only as a proposal to identify a possible means of making information available to homeowners and satisfying all five conditions of the classical diffusion theory.

Simple to Understand. We designed and constructed a ground-based replica on the west side of the Athletics Building. A major intent of the replica is to address the com- plexity of green roof construction. Each of the six layers that comprise the green roof (roof membrane, root barrier, drainage layer, separation fabric, substrate, and plants) is pulled out from the layer above so as to make all layers visible. Signage is affixed to Lexan panels above each layer, providing the name of the material highlighted and its purpose.

Relative Economic and Ecological Advantage. Besides the replica, a larger introductory sign briefly states some of the ecological advantages of green roofs. A 


\section{PLANTS}

Green roof plants must be drought tolerant. Besides covering and keeping the substrate in place, studies have shown that green roof plants soak up rainfall and filter stormwater runoff, protect the roof from ultraviolet radiation, and create habitat for wildlife.

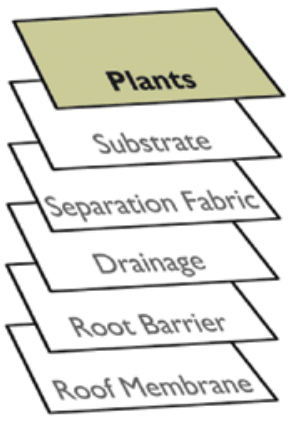

One of six signs placed on the replica, each describing a layer comprising the green roof and its purpose.

Web page may be the best way to address the economic advantages of green roofs by providing links to research literature focusing on cost investments and savings in energy efficiency. Typical suburban homes near Ambler may be hypothetically retrofitted with green roofs on the Web page as well. Proposals can be itemized

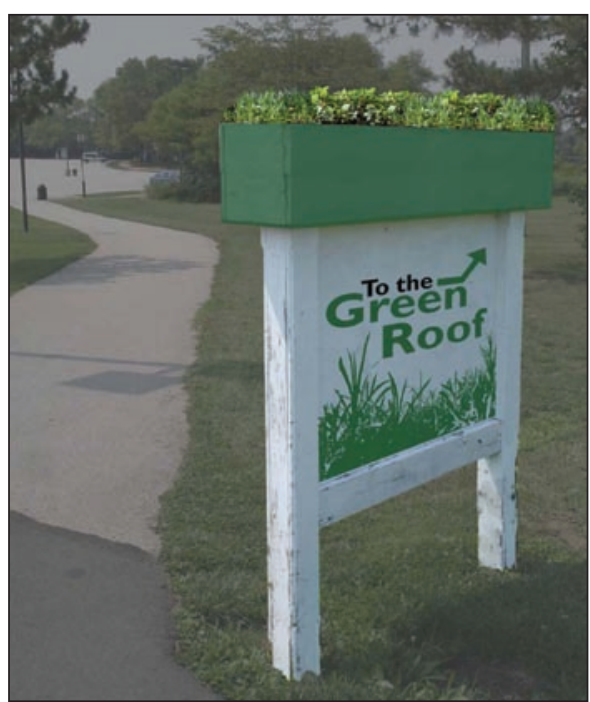

A rendering of a proposed design for modifying an existing wayfinding sign on the path to the green roof. and include installation costs and longterm energy cost savings. Also, links and related information on policies and government incentives such as rebates may be included.

Observed Elsewhere. Taller Sedums, Alliums, and drooping Delosperma species were planted along the perimeter of the green roof to make the roof visible from the ground. The ground-based replica uses identical plants to alert and direct passersby to face the building and look at the roof. Existing wayfinding signs on the path to the green roof will be retrofitted with small green roofs and signs noting the direction of the green roof.A sign placed in front of the Athletics Building will explicitly identify both the building and the
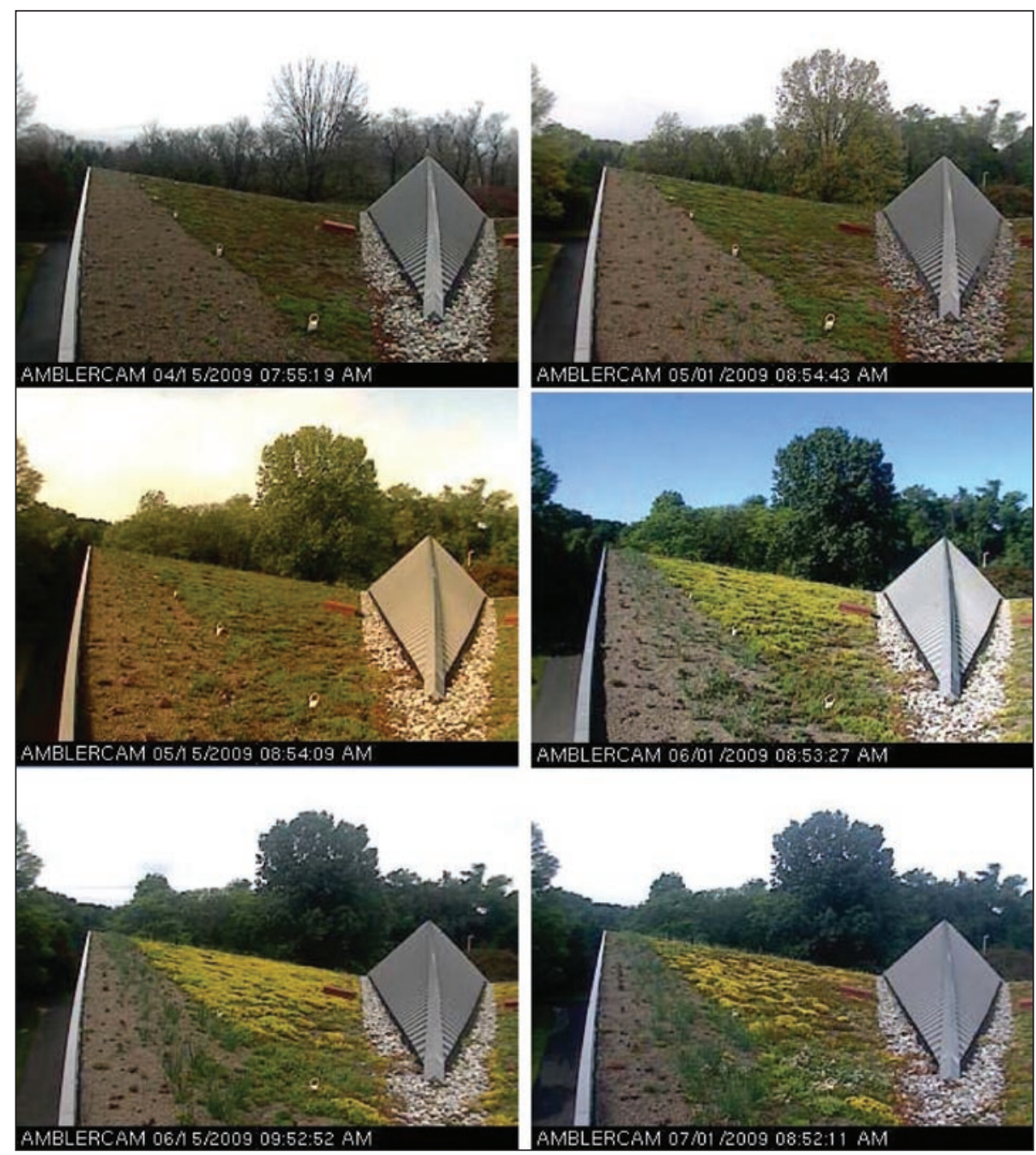

Six still photographs of the green roof were each taken two weeks apart by the Web camera mounted atop the green roof. The six-foot wide perimeter of new planting along the roof's edge clearly changes during this initial period of establishment. 
location to illustrate information regarding such things as structural reinforcement and slope stabilization. The Web page may also provide contact information for local firms, such as Roofscapes who specialize in green roof strategies, as well as suppliers of materials, designers, contractors, and maintenance companies.

Easy to Try. Photographs and notes documenting the design and construction of the ground-based green roof replica illustrate the ease with which a green roof is made and may be uploaded to the proposed Web page. Finally, a blog or Twitter profile focusing on the green roof over the last two seasons and in the future could serve to document the frequency and cost of maintenance, modifications or revisions needed, and repairs made. Blogs or Twitter profiles of other local examples of green roofs besides Ambler's green roof would be necessary to make comparisons and identify similarities of use to homeowners with smaller green roofs.

Our green roof has already received more attention. On the day of the groundbased replica installation, two high school students were there to photograph, film, and interview me for a class project on sustainability in Ambler. With global interest in environmental issues now firmly seated, their generation may be more receptive to such green strategies. A thoughtful and rapid address of the conditions in the classical diffusion theory may still present an opportunity to convince the current generation of suburban college students that the roof of their future home should be green.

\section{ACIKNOWLEDGEMENTS}

Tim Garrett and Rebecca Kagle, landscape architecture students at Temple University, designed and constructed the ground-based green roof replica.
They were also instrumental in administering the survey to Ambler students. Dr. Mike Olszewski, assistant professor of Horticulture, was heavily involved in the selection of plants for the roof and replica. Both he and Dr. Mary Myers reviewed early versions of this work and offered valuable suggestions.

\section{REFERENCES}

Calkins, M. 2005. Strategy use and challenges of ecological design in landscape architecture. Landscape and Urban Planning 75:29-48.

Liptan, T. 2005. The Ecoroof and Me. Landscape Architecture 95(8):105.

Oberndorfer, E., J. Lundholm, B. Bass, R.R. Coffman, H. Doshi, N. Dunnett, S. Gaffin, M. Köhler, K.K.Y. Liu, and B. Rowe. 2007. Green Roofs as Urban Ecosystems: Ecological Structures, Functions, and Services. Bioscience 57(10):823-833.

Smith, C., and M. Boyer. 2007. Who wants to live with a living roof? Green Places (October):24-27. 